Sebastian Muth

\title{
Informal signs as expressions of multilingualism in Chisinau: how individuals shape the public space of a post-Soviet capital
}

\begin{abstract}
Informal and transient displays of written language such as graffiti, announcements and notes attached to walls and lampposts form an integral part of an urban linguistic landscape. Especially within multilingual contexts, individuals constantly shape the public space by the languages they use and make language choices that do not always reflect official language policies, commonly held perceptions or the demographic makeup within a certain area. The capital of the Republic of Moldova, Chisinau, proves to be an interesting area of research here, as - apart from a Romanian-speaking majority - the city is home to a large share of speakers of Russian, a language long considered to be the lingua franca of the country. The aim of the current study is to analyse signs made by private individuals that are not part of shop fronts or billboards, namely those that are found all over the city and advertise for language courses, work opportunities abroad or express political opinions. The quantitative basis of the study is made up of two corpora with over 750 different items from various parts of Chisinau surveyed in 2009 and 2010 both in the centre of the city as well as in suburban residential areas. For better traceability and to ensure transparency in linguistic landscape analysis, the 2010 corpus is accessible online. The survey shows that Russian is widely used as a local lingua franca, contradicting official policies that declare Romanian Moldovan the sole national language.
\end{abstract}

Keywords: linguistic landscapes, informal signs, multilingualism, Moldova

Sebastian Muth: University of Fribourg. E-mail: sebastian.muth@unifr.ch

\section{Introduction: linguistic landscapes and Moldova}

This study analyses informal and transient displays of written language in Chisinau, the capital of the Republic of Moldova. In this article the focus is laid 
on informal displays of written language installed by individuals and private entrepreneurs such as placards, notes or graffiti. This is done by narrowing down the scope of the analysis to signs where language use is neither prescribed nor sanctioned by government bodies or other public actors, but that are parts of a largely unregulated linguistic landscape.

The present study on the cityscape of Chisinau draws from a number of distinct strands in linguistic landscape analysis, among them surveys on ethnolinguistic vitality (Cenoz and Gorter 2006), indigenous languages (Pietikäinen et al. 2011), the symbolic representation of languages and power structures (Ben-Rafael et al. 2006; Woldemariam and Lanza, this issue; Zabrodskaja, this issue), the discourses of globalization, international tourism and trade (Backhaus 2007; Edelman, this issue; Kallen 2010), advertising (Cenoz and Gorter 2009) and sociolinguistic aspects related to language shift and change (Muth 2012; Pavlenko 2009, 2010). Yet apart from a wider context that relates to historical, political and socioeconomic factors, surveys of post-Soviet linguistic landscapes require a refined approach. This includes both quantitative observations on the vitality of languages within a community as well as an ethnographic perspective that considers signs and language in the public sphere as cultural texts that "articulate the cultures that generate them" (Coupland 2010: 78-79; Scollon and Wong Scollon 2003; Stroud and Jegels, this issue; Milani, this issue). Both perspectives are equally important in understanding language change and shift as well as post-Soviet nation-building that is frequently centered on ideologies of the monolingual nation-state (cf. Pavlenko 2011).

The main focus of this article lies in the documentation and interpretation of the vitality and visibility of the country's most widespread minority language Russian and raises the question, to what extent the former lingua franca of the Soviet Union is used by individuals in the cityscape of the Moldovan capital. Similar to other countries of the former USSR, the status of the Russian ethnic minority and their language continues to raise concerns by policymakers and local inhabitants alike. Advocates of policies pursuing a nationalistic revival in countries like Latvia and parts of Ukraine see the language as a burdensome remnant of a Soviet past that needs to be overcome. General tendencies in the post-Soviet realm point towards "derussification" and "de-sovietization" (Pavlenko 2008: 282), processes that have resulted in a significant loss of status and prestige of Russian in the region. Within this context a survey of the informal linguistic landscape of urban Moldova provides insights into patterns of language use by individuals that might help to give us an understanding of the current language situation, the prestige and functional domains of both the titular language Romanian and Russian as a minority language as well as the negotiation of different linguistic identities mirrored in the linguistic landscape. 


\subsection{Language, culture and politics}

Moldova became independent in the wake of the collapse of the Soviet Union in 1991 and "like many other regions along the borderlands of recently dissolved empires, the country is distinctively multi-ethnic and multilingual in character" (Ciscel 2007: 1). It is one of the few countries of the former Eastern Bloc in which a distinct political and cultural identity has not yet emerged and in which a connection to pre-war traditions of statehood has not been possible per se (Hirsch 2005). The stretch of land between Romania and Ukraine had been part of the Russian Empire until the Russian Revolution when most of present-day Moldova was integrated into Romania as the province of Bessarabia (King 2000). After the war, the Moldavian Soviet Republic was established and included both Bessarabia and parts east of the river Dniester that constituted the former Moldavian Autonomous Soviet Socialist Republic (MASSR). The formation of Soviet Moldova went alongside efforts to industrialize the Republic. The region subsequently witnessed a heavy influx of workers from Russia, Ukraine and other parts of the USSR, especially into urban areas. In 1989, an impressive number of 550,000 speakers of Russian lived in Moldova out of a total population of approximately 4.3 million inhabitants (Nygren 2008: 82).

Similar to other parts of the Soviet Union, Russian became the language of wider communication and was essential to know in most domains, while the functions of the titular language Romanian were fairly limited (Ciscel 2007: 12). Its script was changed from Latin to Cyrillic, and Soviet scholars tried to fabricate a distinct Moldovan language to create a distinct Moldovan cultural identity by highlighting linguistic differences between Romanian and the dialect of Moldovan (Rom. Moldovenesc) (Pavlenko 2008: 280).

Language and identity continued to be decisive issues in independent Moldova as well. Already two years before the country became independent in 1991, Romanian in Moldova was changed back from Cyrillic to Latin script and Russian lost its status as an official language. As in many other former Soviet Republics, such as Estonia and Latvia, this left a considerable share of the population with a first language not officially recognized by the authorities. However, policies which would promote the titular languages were not pursued with the same rigor as in the Baltic Republics (Pavlenko 2008, 2011) and until today Russian is spoken by most of the ethnic Russian population in all domains. It is also an L2 for other minority language speakers of the country, including Ukrainian, Gagauz and Bulgarian (Ciscel 2008: 103-104).

The reasons for the current language situation and the strong status of Russian in the country are complex, but the largely failed quest for a genuinely Moldovan political identity as well as work migration and strong economic ties to 
the Russian Federation and Ukraine can be regarded as crucial factors. As such, Moldovan political elites did not succeed in creating such a distinct cultural and political identity after the country's independence, resulting in a low-level national cohesion among the country's inhabitants (King 2000). Although Russian lost its status as an official language following the breakup of the Soviet Union and the independence of Moldova, it is widely used in the economy and the media. This has led to a high degree of uncertainty about the identity of the national language, which is "in stiff competition with Russian for many social functions and roles” (Ciscel 2008: 99).

\section{Methodological aspects: cityscapes in multilingual settings}

A broad definition of what constitutes the linguistic landscape of a given area refers to "any sign or announcement located outside or inside a public institution or a private business in a given geographical location” (Ben-Rafael et al. 2006: 14). This has the advantage of delivering insights on how frequent different languages are visible in the public sphere. Nevertheless, counting signs alone does not tell much about the different authors in the linguistic landscape, their motivations to display or omit certain languages or the specific domains they are used in (Coupland 2010; Jaworski and Thurlow 2010). By adding a discursive perspective to such quantitative observations, it is possible to determine the forms, function and prestige languages have in a multilingual environment such as the Moldovan capital Chisinau. This helps to determine if certain minority languages like Russian are just expressions of cultural belonging that "transcend physical distance" (Coupland 2007: 122) or genuine tools for wider communication within the whole community.

Most of the time urban landscapes are diverse places and neighborhoods usually differ in their demographic makeup, architectural characteristics and status. Bearing this in mind, we cannot expect the same audience, and subsequently the same patterns of language use in city centers as compared to peripheral residential districts with regard to the display of written language in the public sphere. Furthermore, it is important to acknowledge certain factors that might account for a diverse picture in patterns of language use in a linguistic landscape, for example a particular location near a university, school, transport hub or market.

\subsection{Areas of research}

Although Chisinau appears to be rather small and compact with approximately 600,000 inhabitants, it is Moldova's prime transport hub as well as its economic 
and cultural center. Roughly one third of the population claims to speak Russian as a first language (see Table 1) as opposed to almost 60 per cent who state to speak the national language that is considered either Romanian or Moldovan, depending on the political affiliation and cultural views of the individual (Ciscel 2008; King 2000). ${ }^{1}$ Keeping these figures in mind, it can be expected that a survey of informal and transient displays of written language provides insights into everyday patterns of language use by individuals. In that respect, census data can do more than just reflect social reality and plays a "key role in the construction of that reality and in the creation of collective identities" (Barni and Extra 2008: 19).

To ensure a certain degree of representativeness, the discussion is backed up by two corpora. The first corpus comprises a total number of 1309 items collected on various locations in four districts of the Moldovan capital in March 2009. 2 The second corpus includes 744 signs visible on one of the city's main thoroughfares, the centrally located str. Puşkin collected in March 2010. ${ }^{3}$ Both corpora were designed to include all informal displays of written language visible to passersby within a designated area, regardless if they were shop-signs, advertising banners, billboards, placards or examples of transgressive signs. To be able to compare patterns of language use on formal and usually static private signs with informal

1 Although Moldovan is largely considered a dialect of Romanian spoken in the Republic of Moldova as well as in the adjacent Romanian region of Moldavia, the concept of a distinct Moldovan language was introduced during Soviet times to help fabricate a distinct Moldovan cultural and linguistic identity. Today the terms Romanian and Moldovan are used interchangeably when referring to the language spoken in the Republic, but the reference to Romanian suggest a political and cultural orientation towards Romania and Central and Western Europe.

2 This corpus includes the affluent downtown area of Centru, the mixed business and residential district of Rişcani and two peripheral low-prestige residential areas, Botanica and Ciocana. Within Centru, parts of Moldova's main shopping street bulevardul Ştefan cel Mare as well as adjacent streets were surveyed. Furthermore, data has been obtained around the bus and train station and on str. Cosmonauţilor in the north and str. Grenoble in the very south of the district. In Rişcani, sampling areas included segments of its main thoroughfares bd. Renasterii, str. Kiev and bd. Moscova as well as str. Matei Basarab and the eastern part of str. Petricani and around str. B. P. Hasdeu. Within the residential area of Botanica in the south-eastern part of Chisinau, the north-eastern side of the district's main through road bd. Dacia as well as three side streets, str. Independentei, bd. Traian and str. Sofia were considered. In Ciocana, the least prestigious of the four districts located to the north-east of the city, the main roads str. N. Milescu Spătaru and the north-eastern part of str. Vadul lui Voda were surveyed. Also, parts of str. Ginta Latina, str. Otovasca as well as str. Tabacavia Veche were surveyed.

3 All 744 items that constitute the 2010 Chisinau-corpus surveyed on str. Puşkin are available online at http://celum-web.rz.uni-greifswald.de/webgate_anglistik;keyword.html?current ContainerId=175andpageNr=1. This corpus of 744 items includes all specimens of written languages visible on the entire street, ranging approximately 2.5 kilometers from the corner of str. Alexei Mateevici in the south to str. Albişoara in the north. 
Table 1: Mother tongues in Chisinau by district in per cent

\begin{tabular}{lcccc}
\hline & Centru & Rîşcani & Botanica & Ciocana \\
\hline Romanian & 39.4 & 27.5 & 32.2 & 39.9 \\
Moldovan* & 28.7 & 31.6 & 27.5 & 27.2 \\
Russian & 27.5 & 32.7 & 34.0 & 24.2 \\
Ukrainian & 2.4 & 3.3 & 3.2 & 2.8 \\
Gagauz & 0.8 & 0.6 & 0.4 & 0.4 \\
Bulgarian & 0.6 & 0.8 & 0.6 & 0.5 \\
Other; not declared & 0.6 & 3.5 & 2.1 & 5.0 \\
\hline
\end{tabular}

* Moldovan is largely considered to be a dialect of the Romanian language

Source: National Bureau of Statistics of the Republic of Moldova/Moldovan Population Census 2004

displays of written language ranging from graffiti to placards attached to lampposts and trees, both numbers will be presented and discussed. Based on those findings the various functional domains of the languages that constitute the "individuals' linguistic landscape" of Chisinau will be determined. When possible, local informants were asked to provide additional information on the function and purpose of particular signs.

\section{Signs as an expression of language awareness and identity}

When exploring the Moldovan capital on foot for the first time, it is noticeable that the national language Romanian is just one part of a plethora of languages visible to passersby. Whereas shops and international corporations usually display their advertisements in Romanian and occasionally add English catchphrases such as sale, discount center or register now to them, a look at non-static informal signs posted on trees, lampposts or graffiti written on walls reveals a far more diverse picture. These signs made by private individuals and small-scale entrepreneurs often do not convey their message in Romanian alone, but also include Russian to reach their audience. In that respect, a language shift away from Russian towards Romanian as the predominant language of wider communication is at least debatable.

In what follows, the linguistic landscape of the city will be explored from a quantitative angle with a general overview of the distribution of different languages on signs from the two corpora. At first, all signs in a wider sense 
considered to be private displays of written language will be discussed to give a general understanding of the linguistic landscape. After that, the notion of non-governmental and municipal signs will be narrowed down towards the aforementioned units of analysis that include informal and transient signs such as placards, notes, graffiti and other transgressive signs. Besides that, a discussion of selected signs that are to a certain extent representative for the two corpora will help to establish and assign certain functional domains to the languages displayed. Although the notion of transgressive (Scollon and Wong Scollon 2003: 188-189) is not clear-cut and determining a sign that is "in its wrong place" leaves room for interpretation, it allows for a more refined perspective in this particular setting. Unlike an analysis that gives the term private sign a broad definition and includes every display of written language that has not been installed by public and institutional actors, this will show the salience of language boundaries within the private domain.

The audience addressed by signs on a particular street is the same, but nevertheless certain factors might attribute to differences. On the one hand Moldova is, among other post-Soviet nations such as Estonia and Latvia, one of the few European countries that officially regulates language use on static signs such as shop fronts and denies entrepreneurs the sole use of Russian and Cyrillic spelling when naming their establishment (Ciscel 2008: 111). Instead, Latin script has to be used, and shopkeepers who speak Russian as a first language tend to use English instead of Romanian (Muth 2012). On the other hand, informal placards and notes rarely enable the author to include more than one language because of the limited space available to them and the choice to display a particular language is determined by the author's perception of the linguistic environment. In cases where the intentions that lay behind the display of a certain language or the reasons to display that particular sign in the first place were not clear, inquiries with local informants were made.

\subsection{The audience matters - which languages do Moldovans use on signs?}

A quantitative study on the general distribution of different languages on signs in four districts underlines the status of Chisinau as a bilingual Romanian and Russian city, exemplified in Table 2. Considering all informal signs (shop fronts, billboards, placards and graffiti), Romanian is the dominant and preferred code used on more than 70 per cent of all signs, either as the sole language displayed or in conjunction with Russian, English or both. The share of signs that use Russian as one of the preferred codes is slightly smaller and, depending on the 
Table 2: Distribution of languages on non-governmental/municipal signs surveyed in Chisinau by district in per cent $(n=1,309)^{4}$

\begin{tabular}{lclll}
\hline & Centru & Rîşcani & Botanica & Ciocana \\
\hline Romanian & 27.7 & 27.7 & 19.6 & 19.7 \\
Russian & 10.6 & 19.1 & 19.2 & 22.4 \\
Romanian/Russian & 19.1 & 14.2 & 27.8 & 27.3 \\
Romanian/English & 16.5 & 17.5 & 11.0 & 16.9 \\
Russian/English & 3.2 & 6.1 & 2.0 & 2.2 \\
Romanian/Russian/English & 9.5 & 2.7 & 7.8 & 3.8 \\
English & 4.9 & 6.8 & 2.4 & 4.9 \\
Other* & 8.5 & 5.8 & 10.2 & 2.6 \\
\hline
\end{tabular}

* This category includes other multilingual signs

area of research, ranges from just over 40 per cent in downtown Chisinau up to roughly 60 per cent in residential areas such as Botanica or Ciocana.

The data presented in Table 2 also indicates that English found its way into the linguistic landscape, often in conjunction with Romanian. English has a symbolic function and serves as a marker of internationality, an expression of youth culture as well as a neutral alternative for those entrepreneurs who reject Romanian-language shop names. An exclusive focus on informal displays of written language and a more rigid interpretation of the notion of bottom-up signs that just considers placards, notes, graffiti and other transgressive signs in the corpus results in significant differences as shown in Table $3 .^{5}$

The most striking difference is the increased use of Russian on informal signage. In the central district of Chisinau, the number of placards is almost four times as high as the overall count in the same area in Table 2 and even in the residential areas Botanica and Ciocana, the percentage of signs that exclusively use Russian to convey information more than doubles. Along with the dominance of Russian on such informal signs, Romanian on the other hand does not seem to be the preferred code on them. Especially within the two residential areas Botanica and Ciocana, the absence of Romanian on small posters and notes attached to walls and lampposts was striking, and most authors solely relied on Russian to reach their target audience. Bilingual signs in both Russian and Romanian made up just under a quarter of all items surveyed. Those either solely used Russian

4 Also see Muth (2012).

5 The 2009 corpus has an overall count of 284 informal signs. This is a low number given that a total 1,309 items were surveyed, but in the study, no special focus was laid on informal signage. 
Table 3: Distribution of languages on informal signs (placards/notes/graffiti) surveyed in Chisinau by district in per cent $(n=284)$

\begin{tabular}{lcccc}
\hline & Centru & Rîşcani & Botanica & Ciocana \\
\hline Romanian & 16.8 & 20.1 & 12.9 & 12.7 \\
Russian & 39.0 & 35.9 & 37.3 & 41.4 \\
Romanian/Russian & 23.7 & 19.5 & 24.5 & 21.8 \\
Romanian/English & 17.5 & 10.6 & 9.8 & 9.2 \\
Russian/English & 4.3 & 4.1 & 2.9 & 4.7 \\
Romanian/Russian/English & 5.2 & 4.9 & 7.0 & 6.5 \\
English & 2.6 & 3.8 & 4.2 & 2.9 \\
Other* & 0.9 & 1.0 & 1.4 & 0.8 \\
\hline
\end{tabular}

* This category includes other multilingual signs

Table 4: Comparison of languages displayed on informal signs and formal signs and billboards surveyed on str. Puşkin in per cent

\begin{tabular}{lcc}
\hline & Informal & Formal \\
\hline Romanian & 17.5 & 28.3 \\
Russian & 37.2 & 2.0 \\
Romanian/Russian & 15.9 & 21.1 \\
Romanian/English & 16.5 & 17.5 \\
Russian/English & 3.2 & 6.1 \\
English & 9.5 & 2.7 \\
Multilingual/other* & 4.9 & 6.8 \\
& $(\mathrm{n}=497)$ & $(\mathrm{n}=247)$ \\
\hline
\end{tabular}

* This category mainly includes trilingual signs that display Romanian, Russian and English

and just depicted an address or a shop name in Romanian or provided the audience with information in both languages.

The second corpus compiled in March 2010 on str. Puşkin in the Centru district confirms the strong presence of Russian on informal signage. The corpus presented in Table 4 consists of a total of 744 items and, unlike the first corpus, attempts to cover all specimens of written language visible in a predefined area. The relatively high number of informal signs when compared to the first corpus can be attributed to the high number of placards attached to trees in downtown Chisinau, especially around the intersection of str. Puşkin and bul. Ştefan cel Mare as well as in the western section of the street adjacent to the State University of Moldova, USM. The number of informal signs that use Romanian confirms the findings in Table 3, but an overall decrease in the use of the national language is 
visible when moving away from the core area of the city that is constituted by the Centru and Rişcani districts. The observations on str. Puşkin showed that individuals and political groups rarely express themselves through transgressive signs, the only exemption are stickers by pro-Romanian political pressure groups attached to billboards, occasional personal messages like "I love you" in Russian as well as additions made to Romanian-language road signs, usually in the form of a direct translation into Russian. These patterns were also observed in other parts of the city, but most of the time those were personal messages scribbled on walls in Russian or occasionally in English. English does not share the same functional domains as Romanian or Russian and is used symbolically to highlight a certain international orientation and to appeal to young people, a pattern observed in various settings. It is a language associated with upper social strata, but in a broader sense a language of "international orientation, modernity, success, sophistication and fun" (Cenoz and Gorter 2009: 57; Edelman, this issue). Most of the time, English catch-phrases were displayed on small placards and notes advertising language courses, opportunities to work and study abroad or concerts by local and foreign pop artists.

The cityscape has been approached from an empirical angle that confirms the initial claim that the urban space of Chisinau is predominantly bilingual Romanian and Russian. But, as a linguistic landscape in itself is a highly complex sociolinguistic phenomenon, a quantitative observation of a large number of signs of different genres only does not necessarily lead to meaningful and generalisable results concerning patterns of language use by individuals. Counting signs might be a good way to learn about general patterns of language use within a community, but tends to neglect such factors as language variation, language contact phenomena as well as authorship and specific type of sign (Coupland 2010). Especially when making assumptions on the spread, function and vitality of a language within a community, counting different languages on shop signs and billboards alone does not necessarily provide new perspectives with generalisable data on the language situation in a given community. Instead such data shall serve as a foundation for a further discursive analysis of signs and a thorough study of the forms and functions of publicly visible written language in a cityscape.

\subsection{A close-up look - forms and functions of informal signs}

A close-up look on informal signage is crucial in order to determine specific functional domains and the status of the various languages that constitute the linguistic landscape of the city. In order to provide for a broad perspective on the differ- 
ent forms and functions of such signs, a select number of items from both corpora that serve as typical examples of the informal displays of written language observed will be discussed. For such a discursive perspective, a categorisation of the most common forms of informal signage surveyed is essential. At first, forms and functions of advertising posters and placards, the most common form of informal signs found in the linguistic landscape, will be discussed. This category is a very common type of informal sign and the information given on them is "considered relevant for a certain amount of time” (Reh 2004: 4).

Focus will be laid on transgressive advertising that was used mainly in peripheral areas and includes phone numbers and small advertisements sprayed or painted on walls. These advertisements are a common phenomenon in countries in the developing world. In her study of multilingual writing in Ugandan municipalities, Reh (2004: 4) labels them as “written announcements", a categorisation that can also be applied to the linguistic landscape of Chisinau. They are flexible in use and may be "computer-written or handwritten", often put up by individuals selling products or announcing sporting events (Reh 2004: 4). Transgressive notes by individuals, often observed in the form of small messages scribbled on walls or park benches, are closely related to the latter category, but have to be discussed separately here. The forms of such messages are certainly equal to transgressive advertising, but the functions are entirely different, as these are not intended to sell goods and services or announce events, but instead are transgressive texts that are intended to locate the author "within a particular spatial, class and ethnic subculture of the city" (Pennycook 2009: 307). This will be concluded by a look at a fourth category labeled political messages and alterations to the linguistic landscape. In this group the focus is laid on informal signage by political activists. This also incorporates makeshift Russian-language street signs displayed in addition to already existing top-down signage in Romanian.

\subsubsection{Advertising posters and placards}

The city center is characterised by a plethora of informal signs by both smallscale businesses and individuals alike. The first item shown in Figure 1 is part of the 2010 corpus and exemplifies a very common phenomenon observed in all cities throughout Moldova and highlights the popularity of foreign language learning especially by young Moldovans. The sign was attached to a tree and located on str. Puşkin close to the main building of the State University of Moldova USM.

Initially one has to define it as a multilingual sign, depicting among other languages Romanian, Russian, Latin and English. Still one clearly notices a 


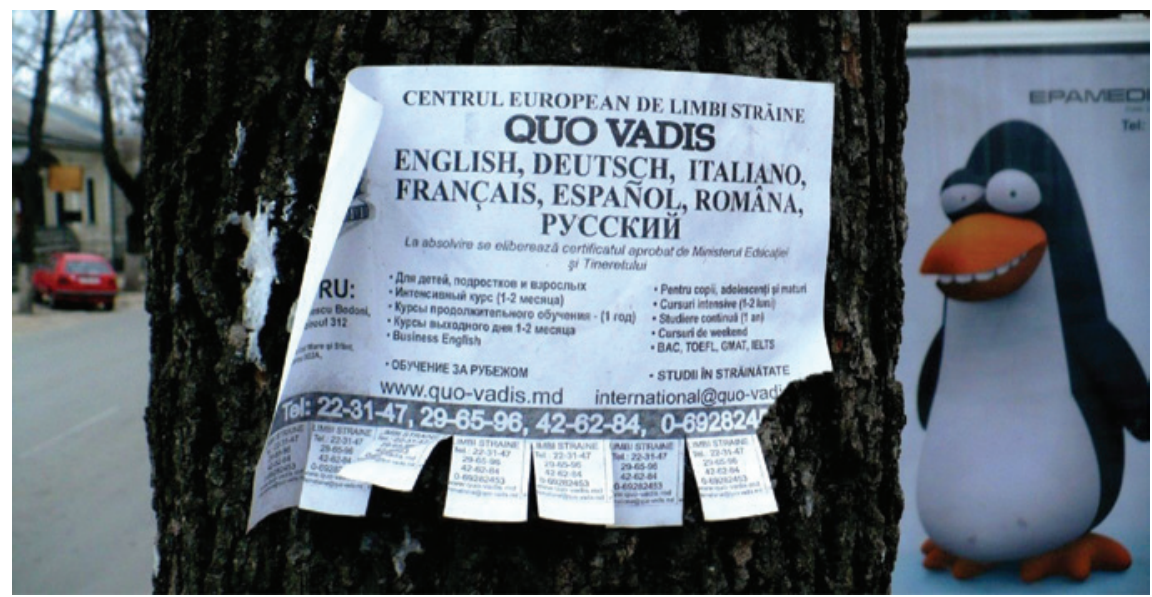

Fig. 1: Multilingual sign of the "European Center for Foreign Languages Quo Vadis” on str. Puşkin (Centru district), offering a wide range of language courses

pattern recognizable on many comparable items in the linguistic landscape of Chisinau, namely a clear-cut distinction between the informative and symbolic meaning of the different codes, one of the main dichotomies introduced by Landry and Bourhis (1997). The addressee will recognise eight different languages; the only ones that actually carry information in order to understand the message of this advertisement are Russian and Romanian. The name of the establishment, Centrul European de Limbi Străine Quo Vadis ${ }^{6}$ is expressed in both Romanian and Latin, with the Latin phrase Quo Vadis having a multilayered meaning considering the rather grim perspectives of young Moldovans at the moment, but the course details and various offerings depicted beneath are given in Russian and Romanian. Both languages share equal space and font and it appears that the placard is not aimed at any particular speech community but tries to include as many recipients as possible. In addition to that, already documented features of the cityscape of the Moldovan capital (Muth 2012) can be observed: on the one hand, the offer to study abroad, Rus. Обучение за рубежом, Rom. Studii în Străinătate, provided in both languages right above the center's contact details; on the other hand, catchphrases such as "international" and "Business English" depicted as part of the email-address of the establishment.

Another example from downtown Chisinau that is part of the 2009 corpus was taken on the main artery of the city, bul. Ştefan cel Mare, in close proximity

6 European Centre of Foreign Languages Quo Vadis. 


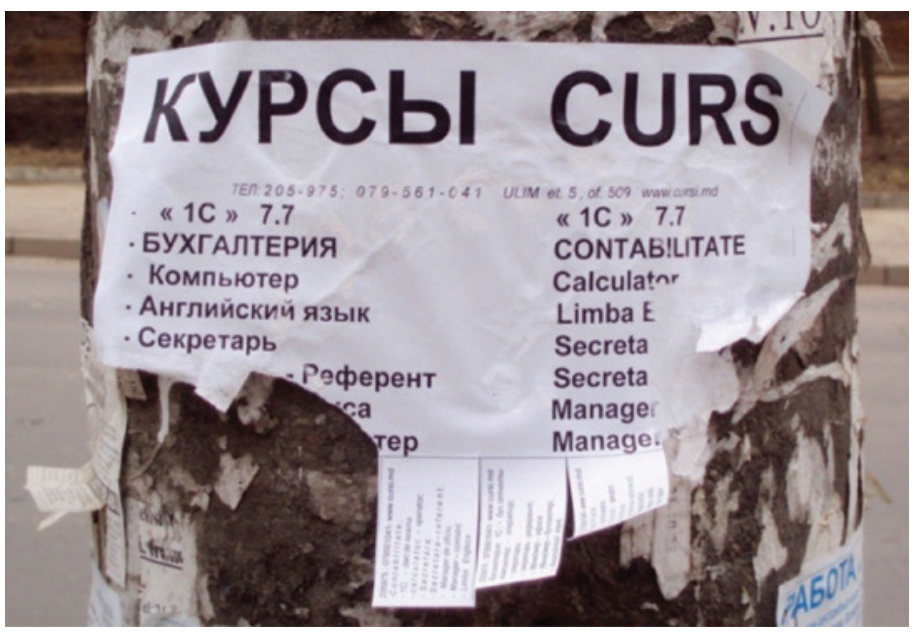

Fig. 2: Bilingual Russian-Romanian sign offering courses to become an accountant on bul. Ştefan cel Mare (Centru district)

to both the Moldovan Parliament and the Presidential Palace and was attached to a lamppost. It is shown in Figure 2 and represents a bilingual Russian-Romanian placard promoting courses to become an accountant. The two languages share equal space and font, but contrary to Figure 1 the distribution of both Russian and Romanian is equal and neither of the two is dominant on the sign. As the degree of repetition of the content is high, it is a typical bilingual sign (Reh. 2004: 3). The contents and key components of the course are given as direct translations in both languages and even the stubs people ought to take home as a reference are bilingual, showing the willingness of the linguistic landscape actors to reach the widest audience possible. This pattern goes along with a willingness to use both languages interchangeably. On the one hand, the Russian abbreviation ТЕЛ for telephone is used in the upper left-hand side of the placard; on the other hand, the Romanian abbreviations for floor, et. (nom. etajul) and office, of. (nom. oficul) are found in the same line. The web address www.cursi.md is given in Romanian, but would allow for an interpretation in Russian as well, as the phonetic realization of the plural form of the Russian noun курсы is in fact quite close.

Figure 3 is a typical example of an informal, non-static sign that uses Russian to convey actual information and English to symbolize a certain degree of internationality and worldliness. It is an advertisement from the 2010 corpus placed by a small Fitness-Club calling itself FitoSHAPE, offering different fitness classes. 


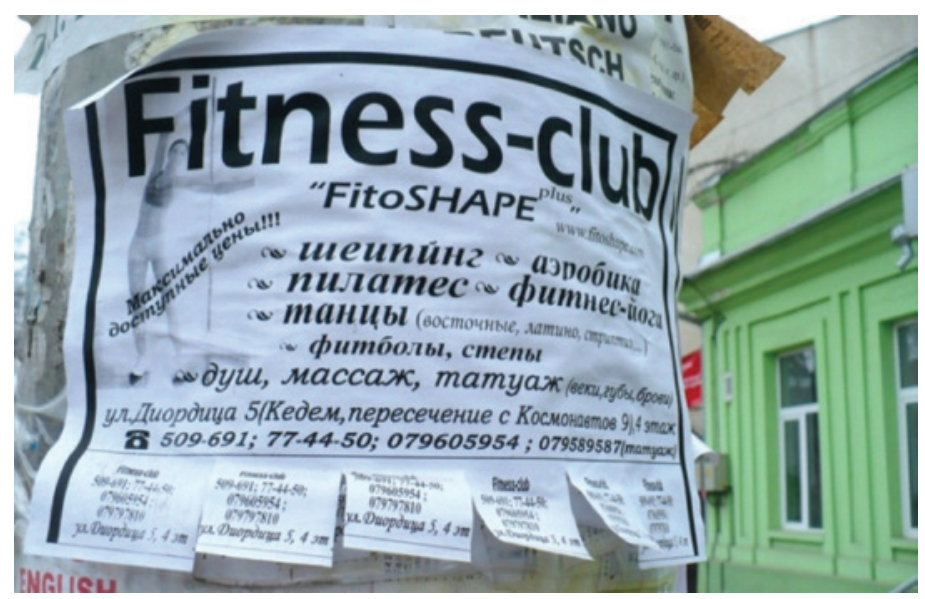

Fig. 3: Bilingual Russian-English sign advertising for fitness classes on str. Puşkin (Centru district)

The actual activities are depicted in Cyrillic and include Russian loan translations such аs аэробика (aerobics), фитнесс-йога (fitness-yoga) and cтепы, shortened from 'step-aerobics'. Furthermore, English pseudo-loan such as шеипйнг 'shaping' as well as Russian words as футболы 'footballs'7 and душ 'shower' appeared. The address of FitoSHAPE in the lower part of the placard is written in Russian as well, but one of the street names mentioned - ул. Диордица is a transliteration of the Romanian name str. Diordiţă, whereas ул. Космонавтов is the Russian version of the Romanian name of the street, str. Cosmonauţilor. Кедем, the actual name of the place the courses are held in, is a Russian-language acronym for Кишиневский единый дом евреев Молдовы, known as 'Moldova's Joint Jewish Center in Kishinev'. Although the remainder of the Jewish population of Chisinau mostly speaks Russian, the placard is aimed at all passersby interested in gym-classes. Russian is the language of choice as the authors most likely assumed that L1-speakers of Romanian have the ability to comprehend Russian.

The characteristics of Figure 4 from the 2009 corpus underline this claim. This placard offering to buy hair was found in the district of Ciocana on str. N. Milescu Spătaru, a neighborhood characterised by multistory apartment blocks from the Soviet area. It is written predominantly in Russian apart from the Roma-

7 The use of the plural form футболы 'footballs' is unusual and suggest that the author is no L1-speaker of Russian; if the author of the sign wanted to indicate that it is possible to play soccer during their classes the singular form футбол 'football, soccer' would have been appropriate. 


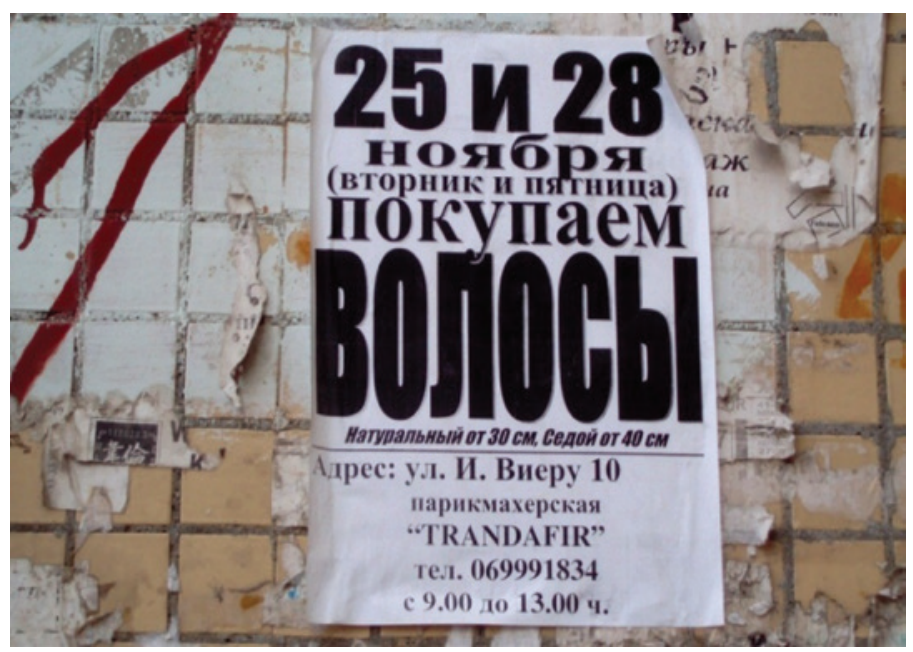

Fig. 4: Monolingual Russian placard offering to buy hair on str. N. Milescu Spătaru (Ciocana district)

nian name of the establishment, TRANDAFIR 'rose' set in inverted commas. All of the actual information the audience needs in order to understand is written in Russian, dominated by the catchphrase ВОЛОСЫ, the Russian plural form for 'hair'. Similar placards were found throughout the city in central as well as peripheral areas and the authors exclusively used Russian on them. From a contextual perspective these placards highlight the bleak economic situation many Moldovans are facing today. Given the limited space placards offer and the fact that speakers of Russian and Romanian are equally affected by a largely failed economic transition, Russian was chosen because the authors most likely assumed that the use of this language enables them to reach the widest audience possible.

Figures 5 and 6 represent one bilingual Romanian-English as well as one predominantly English sign. They are part of the 2010 corpus and were taken near the main building of the State University of Moldova USM. Similar to Figure 1, both are aimed at students, promoting the "Work and Travel USA" program that is very popular among young Moldovans. It offers the opportunity to spend a year in the United States, mainly working in the service sector of the American economy. Apart from providing the opportunity to travel through the US after having worked for a certain time, the program also allows participants to reclaim income taxes earned once they arrive back in Moldova. Most agencies rely on such placards attached to trees or lampposts, preferably near institutions of higher education. 


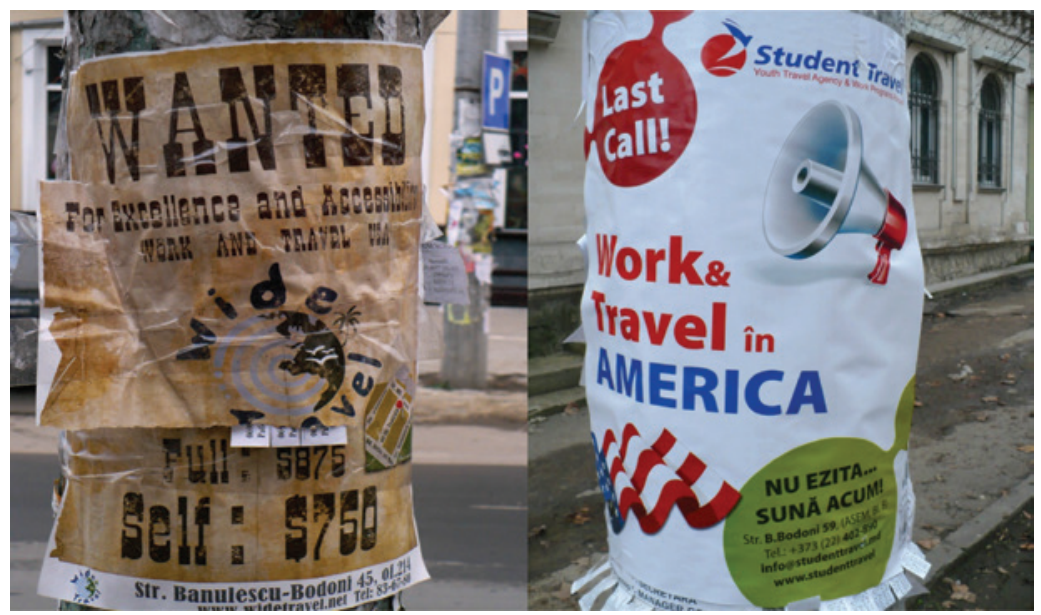

Fig. 5 and Fig. 6: Two placards promoting the "Work and Travel USA" program on str. Puşkin (Centru district)

The use of English on both placards is an obvious choice, as those potentially interested in the program will have a sufficient command of English. Still, English has a much more important symbolic function on both signs that signals modernity, success and an international orientation. "Student Travel" relies on an American flag and a matching color combination, while the exclamation "Last Call" and a stylised megaphone suggest that the observer has to act immediately in order to get into the program. This is reinforced in Romanian in the lower part of the placard, stating NU EZITA ... SUNĂ ACUM! 'don't hesitate ... call now'. "Wide travel" on the other hand employs a theme from the American West and displays a wanted poster that includes the obvious catchphrase as well as the dollar sign to appeal to a wide audience and their image of the United States. Russian was almost never used on such placards; other agencies mostly used Romanian and English on their placards.

\subsubsection{Transgressive advertising}

The urban landscape in the northern part of str. Puşkin is characterized by car repair shops, public utility companies, other public institutions and apartment blocks. The forms of informal signage differ if compared to the core area of the city around the intersection of str. Puşkin and bul. Ştefan cel Mare. Because of the small number of shops in that particular area, the linguistic landscape of the 


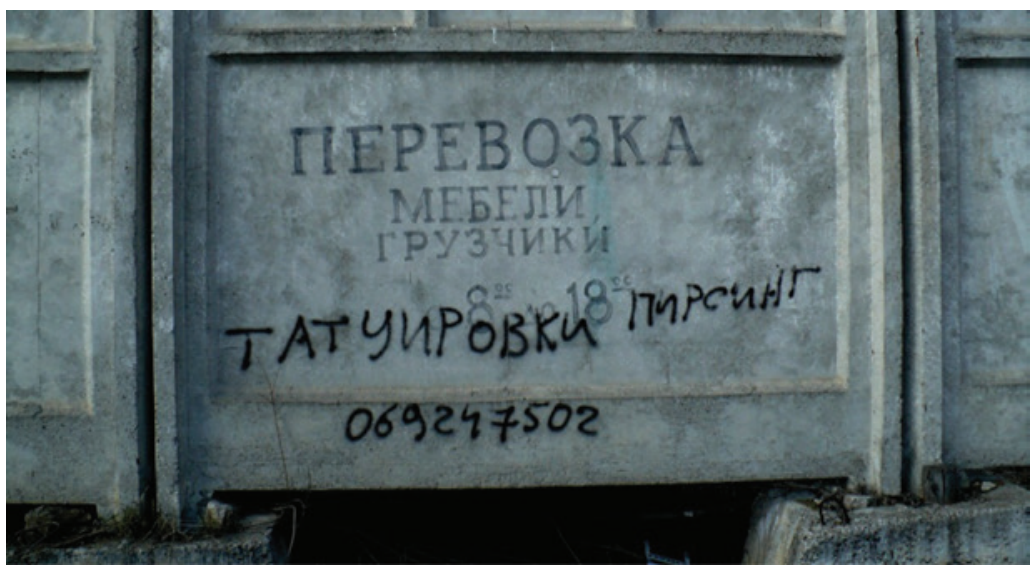

Fig. 7: Two Russian-language advertisements, one by a transport company, the other by an individual offering tattoos and piercings on the northern end of str. Puşkin (Centru district)

neighborhood is dominated by informal signs in Russian. Figure 7 taken from the 2010 corpus represents two prototypical examples that were either painted or sprayed on a wall. The sign on the top is an advertisement for a moving and transport company that was located right next to the sign but seemed to be out of business. Below that, an example of a transgressive advertisement offering tattoos (татуировки) and piercings (пирсинг) is shown. Both are English loanwords that have been integrated into Russian. A local phone number is given as well, signaling that this sign is not graffiti, but an advertisement that might be aimed at teenagers attending a nearby school.

A similar advertisement was found on str. B. P. Hasdeu in Rişcani shown in Figure 8 (2009 corpus). It was sprayed on a house wall and after inquiring about the sign, locals living nearby claimed that nobody gave permission for it. It is a bilingual Russian-English sign similar in its language choice to advertisements on billboards and bus stops by enterprises selling IT-hardware. On this particular sign, English serves as a tool that enables the observer to connect to Englishlanguage computer terminology ("GIGABYTE computers") and to well-known catchphrases used on signs in the retail trade throughout Chisinau ("save"). The company logo, a stylized "G" for GIGABYTE is presented as a sophisticated icon for the brand that can be easily recognised. Russian complements the meaning of the message by announcing big discounts and savings, but the audience has to be able to comprehend either parts of the company's name, "GIGABYTE" or "computers" to understand what the company has to offer. The Russian catchphrase экономь с нами 'save with us', that corresponds with the web address of the 


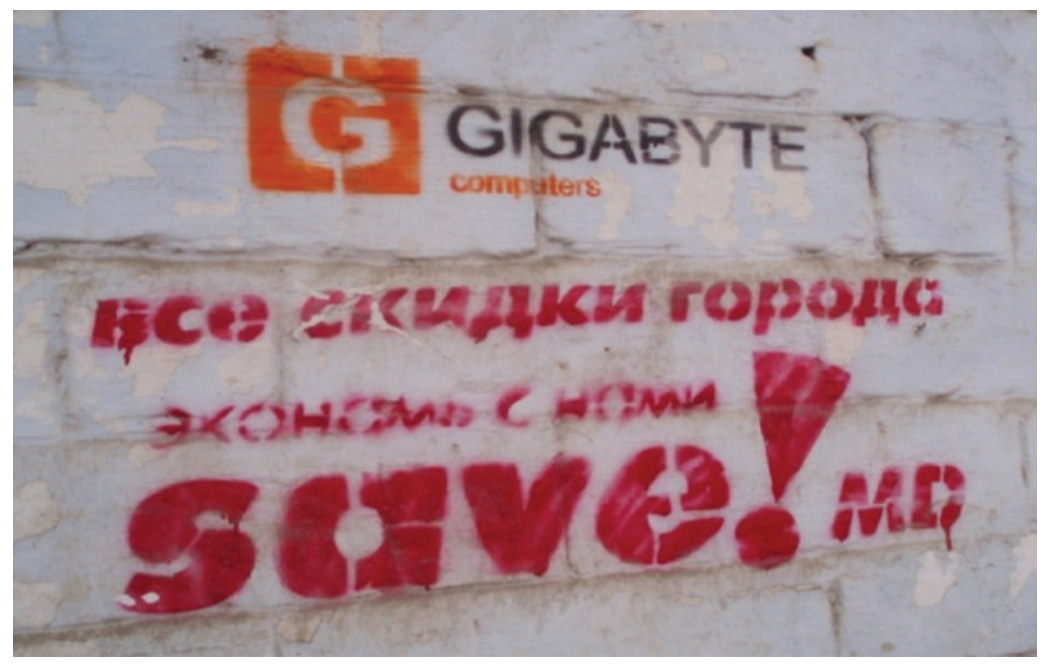

Fig. 8: Bilingual Russian-English advertisement for an electronics outlet on str. B. P. Hasdeu (Rişcani district)

company, is depicted above the web address. The reason why Romanian is not used might lie in the transgressive nature of the sign and the limited space available to the author(s), but nevertheless a combination of Russian and English was chosen to appeal to their potential customers.

\subsubsection{Transgressive notes}

Figures 9 and 10 show one of the few examples of transgressive notes surveyed in the city. Both are part of the 2009 corpus and were taken on str. 31. August 1989 in front of the National Palace (Palatul Naţional), a popular concert venue in downtown Chisinau.

Both pictures are typical visual expressions by local teenagers and usually Russian, Romanian and English are used. Unlike graffiti that is "generally not intended to be interpretable by people outside the subculture of hip-hop/graff writers" (Pennycook 2009: 307), the authors of such notes intend to communicate their message to a wide audience and are probably aware of the language choices they make. In Figure 9 Russian is used to tell the world that Vlad plus Dasha equals love, symbolised by a heart. In Figure 10 passersby learn that Romanian-speaking Ana and Oleg are passionately in love, yet they had doubts on how to spell puternica 'passionate, intense' right. Obviously nothing is known 


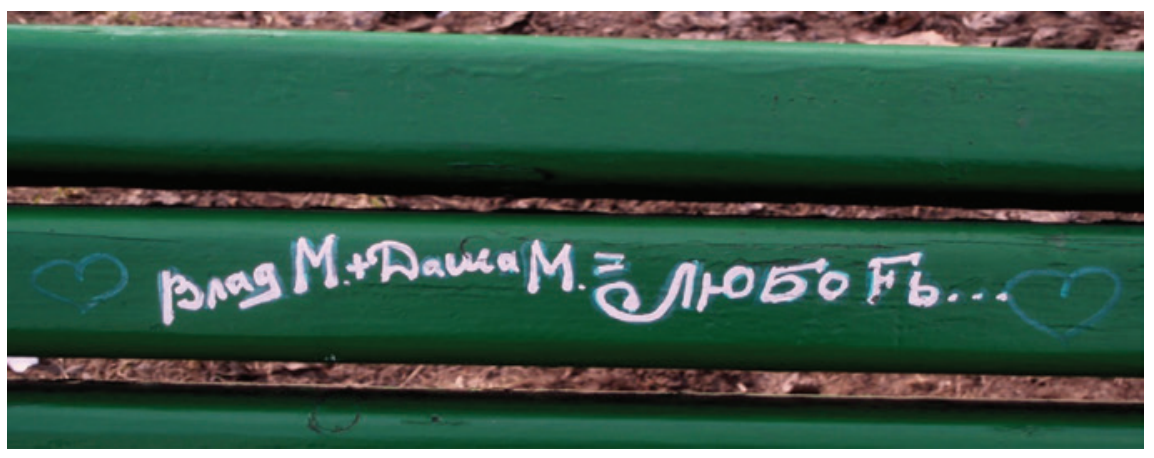

Fig. 9: Love note in Russian in front of the National palace near str. 31. August 1989 (Centru district)

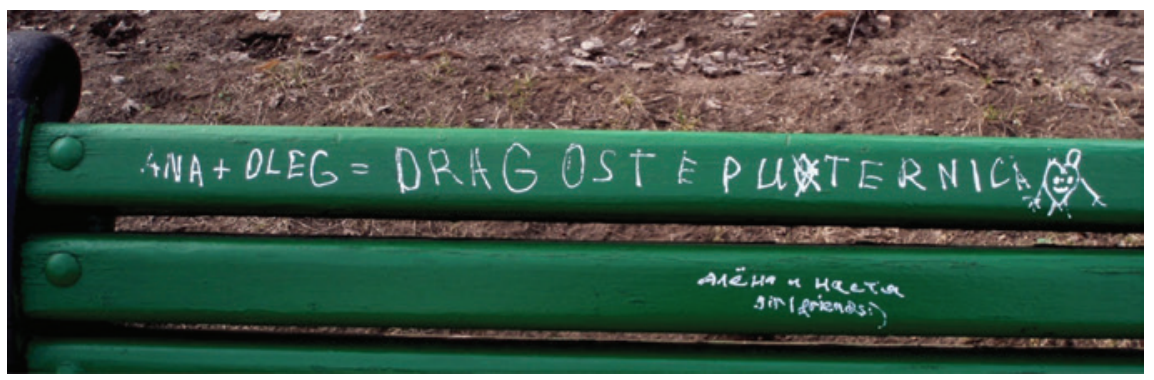

Fig. 10: Love notes in Russian, Romanian and English in front of the National palace near str. 31. August 1989 (Centru district)

about the authors or their intentions. It could either be a hoax or written by the very same persons mentioned, but it can be assumed that each individual chooses to express such a message in his or her own mother tongue or in the language of those they interact with. Nevertheless, just by looking at names written on a park bench it becomes clear that Vlad is not only a nickname of the Russian name Vladimir, but a common name among Romanian-speaking Moldovans as well. Oleg, who is referred to in Romanian, is a name rather used among speakers of Russian than among those who speak Romanian, at least allowing the assumption that they are growing up in a bilingual environment. The third note reads that Alena and Nastja are girlfriends. Their names are written in Russian, but underlined by the English word "girlfriends" and a symbolic smiley, both known and understood in many parts of the world especially by young people. The use of English in this particular case does not tell us much about language proficiency 
in Moldova. Rather, it tells that the authors were aware of the symbolic meaning of their expressions and were sure that others would understand them as well. As there is also no expression for the term girlfriend in Russian that can be used with the same meaning as the English equivalent, one can assume that it might be a conventionalized borrowing in local youth speech.

\subsubsection{Political messages and alterations in the linguistic landscape}

Informal signage by individuals or private businesses had no political implications in the linguistic landscape of Chisinau per se, but political slogans by rightwing political groups that displayed anti-Russian and anti-Soviet slogans sprayed on walls and lampposts were visible throughout the city. The example shown in Figure 11 is part of the first corpus and was surveyed in spring 2009, a time of political tension right before the parliamentary elections that led to civic unrest and the toppling of longtime president Vladimir Voronin (Ciscel 2007; King 2000). Obviously, the example is written in Romanian and states that June 22, 1941, the day of Germany's and Romania's attack on the Soviet Union, was the beginning of the liberation of Bessarabia, a historic name of the stretch of land between the Prut and Dniester rivers that largely constitutes contemporary Moldova but excludes those parts dominated by ethnic Slavs in present-day Transnistria. ${ }^{8}$ The date known to many in the region and the Romanian word INCEPUTUL 'beginning' dominate the sign and are intended to catch the eye of passersby. The goal of rightwing groups such as Basarabia Pământ Românesc ${ }^{9}$ lies in the quest for a "Greater Romania" that includes Moldova and rejects any cultural or political influence from neighboring Slavic nations. Nevertheless this sign was one of the few informal displays of written language that actually depicted only Romanian.

Figure 12 is another example from the 2009 corpus where the use of a particular language alone could already be interpreted as a political statement. It was found on str. B. P. Hasdeu in Rişcani. Street names in Cyrillic painted next to official street signs that only use Latin script are a common sight in Chisinau. In this

\footnotetext{
8 Transnistria is a breakaway republic on the territory of Moldova east of the Dniester River that declared independence after the breakup of the Soviet Union. Roughly 65 per cent of Transnistria's population speaks either Russian or Ukrainian as a mother tongue. Although it is officially trilingual Russian, Ukrainian and Moldovan (Romanian written in Cyrillic), Russian is the language of choice in all domains. Consider King (2000) for a comprehensive view on the reasons of this conflict.
}

9 Eng. 'Bessarabia is Romanian soil'. 


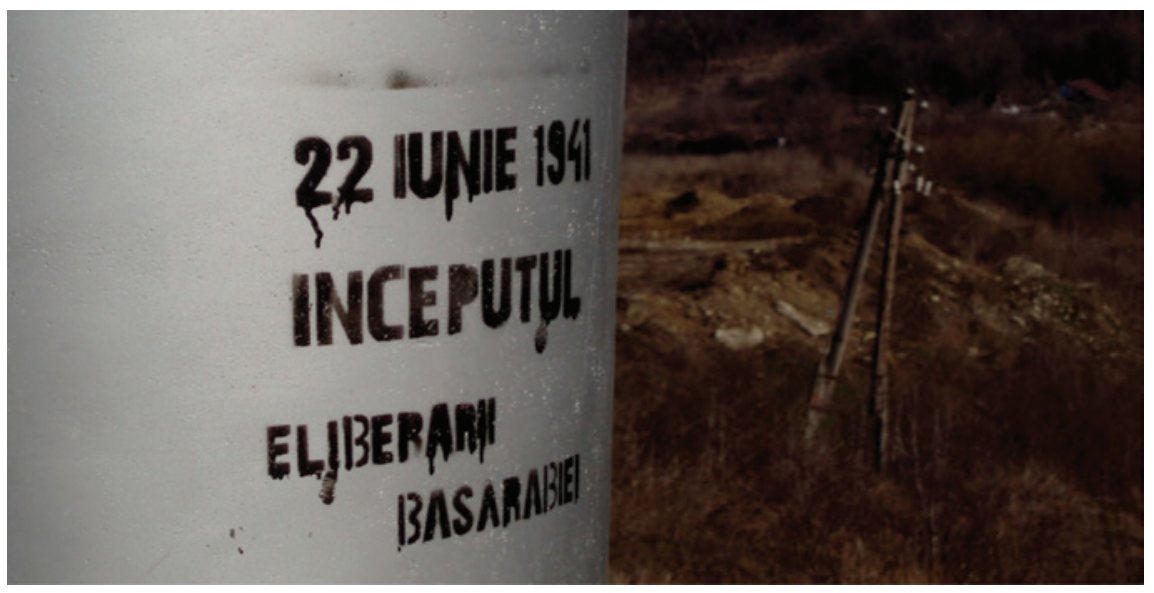

Fig. 11: Slogan of a rightwing anti-Russian pressure group on bd. Renaşterii next to the city's circus (Rişcani district)

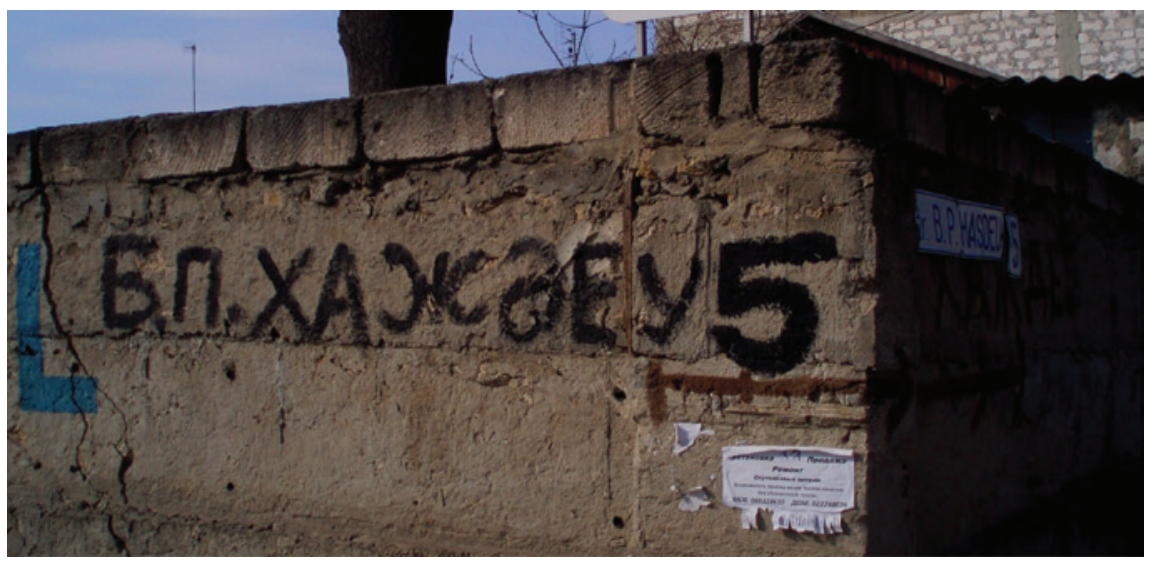

Fig. 12: Cyrillic street name painted on a wall in addition to the official street sign in Romanian on str. B. P. Hasdeu (Rişcani)

case, the address of a repair shop, Б. П. ХАЖДЕУ 5 ‘str. В. P. Hasdeu’ was painted on a wall at an intersection by the owner. One assumes that the obvious reason to transliterate the very same street name into Cyrillic letters might be related to feelings of oppression, the marginalisation of Russian in some domains and discontent with the fact that Romanian is the sole national language of the country. Yet it was possible to get hold of passersby who confirmed that there were 
probably no political intensions behind it. They assumed that some of the repair shop's Russian-speaking customers were not able to read the street name in Latin script and thus the Cyrillic form was added to the wall. This observation highlights the economic function of signs and shows the eagerness of linguistic landscape actors to react to communication problems and "avoid their costs" (Cenoz and Gorter 2009: 66). Nevertheless, such alterations also bear an underlying political dimension and, in general, language choice of private actors "cannot be divorced from the larger political context in which they operate" (Trumper-Hecht 2009: 250). Trumper-Hecht (2009) discusses patterns of language use on signs in several Israeli municipalities and similar patterns apply to the Moldovan capital. Throughout Chisinau, one also notices older street signs from Soviet times where the Cyrillic version was either crossed out or deliberately removed, a pattern observed in other bi- and multilingual communities were official language policies are contested (cf. Sloboda et al. 2010).

Generally, Russian is the language of choice when conveying information necessary to understand the meaning of an informal sign. Especially in informal advertising, signs that just display Romanian are not common, as authors are probably aware that this would unnecessarily limit the reach of their advertisement. Russian, on the other hand, seems to function as a local lingua franca as linguistic landscape actors seem to be aware of the ability of many ethnic Moldovans to navigate the public sphere in Russian. Transgressive advertising showed the same patterns, and practical reasons such as the confined space available to the author might be attributed to the dominance of Russian on them. The domains Romanian was used in on informal signs was limited to posters announcing pop concerts, offering opportunities to study or work abroad, and political slogans. Instances of code-mixing on displays of written language as observed by Zabrodskaja (this issue) in post-Soviet Estonia were unexpectedly scarce. Although Moldovans do not necessarily adhere to standard Romanian or Russian in oral communication (Ciscel 2007; 2008), variation and the use of non-standard expressions was unusual.

\section{Concluding remarks: Chisinau as a bilingual metropolis?}

Informal displays of written language constitute the majority of signs in the linguistic landscape of Chisinau and are an expression of the bilingual language situation in the city. On informal and transient signage, individuals and private businesses are free to choose whichever language they deem suited to communi- 
cate their message to the public and most of them choose Russian. This is surprising to a certain degree as demographic data in Table 1 shows that Russian is a minority language in the city and in most parts of the country as well. In Chisinau, it is spoken by roughly 20 per cent as an L1, but because of its strong presence in the media and in the economic sector, and due to its historic legacy as the lingua franca of the USSR it prevails as the second language of the city and as a language of interethnic communication throughout Moldova (Ciscel 2008: 108-109). On a broader scale, a comparative perspective related to surveys of the linguistic landscapes of other post-Soviet countries shows that the Moldovan capital is no usual case. Such a continuously strong status of Russian is rather uncommon in many former Soviet republics and scholars have observed a decline of functional domains of Russian primarily in Estonia (Rannut 2008), Latvia (Pavlenko 2011), Ukraine (Bilaniuk and Melnyk 2008; Pavlenko 2011) and, to a certain extent, Kazakhstan (Smagulova 2008). In many parts of the former USSR, “derussification” and “de-sovietization” (Pavlenko 2008: 282; Pavlenko 2011) are common phenomena. Although pro-Romanian political elites and pressure groups continue to further confine Russian to the status of a home language, it is an integral part of the linguistic landscape of the Moldovan capital. Because of the promotion of Romanian as the national language, Russian has lost ground in Moldova and is rarely seen on top-down signage by government bodies and other public institutions.

In the private domain, however, bilingual Romanian-Russian shop signs and billboards are a common phenomenon. On informal signs, Russian even seems to dominate the linguistic landscape, leading to the assumption that in certain domains like advertising, linguistic landscape actors accommodate Russophones to reach a wider audience or sometimes to deliberately target specific language groups. Romanian is more prevalent on top-down signs and the second corpus confirmed that on unregulated informal signage, monolingual Romanian signs were not frequently observed. English is often used on signs aimed the socially mobile, signaling internationality, openness and modernity. On transgressive signs, it is used in a more or less superficial way, highlighting the author's readiness to express certain catchphrases presumably known to the public, although it is rarely used to convey actual information.

The findings of this study point towards further possibilities in linguistic landscape research, especially in bi- and multilingual areas where language use is contested and where claims that predict language shifts can be taken into question. Although a survey of informal signage within a cityscape does not necessarily give finite answers to universal patterns of language use, it provides for insights on how individuals perceive the languages spoken in their community regardless of top-down policies and regulations. As to the question whether 
Chisinau is a genuinely bilingual metropolis that has not disposed of its former lingua franca, we can attest that Russian is far from being marginalised. On the contrary, Russian is the individual's first language of expression, at least on publicly visible displays of written language.

Acknowledgments: I would like to thank Anastassia Zabrodskaja from the University of Tartu/Tallinn University for her valuable comments as well as JanPeter Abraham from the German Academic Exchange Service DAAD in Chisinau for providing insights into the physical and historic landscape of the city. All mistakes are entirely my own.

\section{References}

Backhaus, Peter. 2007. Linguistic landscapes - A comparative study of urban multilingualism in Tokyo. Clevedon: Multilingual Matters.

Barni, Monica \& Guus Extra. 2008. Mapping linguistic diversity in multicultural contexts: Cross-national and cross-linguistic perspectives. In Monica Barni \& Guus Extra (eds.), Mapping linguistic diversity in multicultural contexts, 3-41. Berlin \& New York: Mouton de Gruyter.

Ben-Rafael, Eliezer, Elana Shohamy, Muhammad H. Amara \& Nira Trumper-Hecht. 2006. Linguistic landscape as symbolic construction of the public space: The case of Israel. In Durk Gorter (ed.), Linguistic landscape: A new approach to multilingualism, 7-30. Clevedon: Multilingual Matters.

Bilaniuk, Laada \& Svitlana Melnyk. 2008. A tense and shifting balance: Bilingualism and education in Ukraine. In Aneta Pavlenko (ed.), Multilingualism in post-Soviet countries, 66-98. Clevedon: Multilingual Matters.

Cenoz, Jasone \& Durk Gorter. 2006. Linguistic landscape and minority languages. In Durk Gorter (ed.), Linguistic landscape: A new approach to multilingualism, 67-80. Clevedon: Multilingual Matters.

Cenoz, Jasone \& Durk Gorter. 2009. Language economy and linguistic landscape. In Elana Shohamy \& Durk Gorter (eds.), Linguistic landscapes: Expanding the scenery, 55-69. London \& New York: Routledge.

Ciscel, Matthew H. 2007. The language of the Moldovans. Lanham: Lexington Books.

Ciscel, Matthew H. 2008. Uneasy compromise: Language and education in Moldova. In Aneta Pavlenko (ed.), Multilingualism in post-Soviet countries, 99-121. Clevedon: Multilingual Matters.

Coupland, Nikolas. 2007. Style: Language variation and identity. Cambridge: Cambridge University Press.

Coupland, Nikolas. 2010. Welsh linguistic landscapes 'from above' and 'from below'. In Adam Jaworski \& Crispin Thurlow (eds.), Semiotic landscapes: Language, image, space, 77-101. London \& New York: Continuum.

Hirsch, Francine. 2005. Empire of nations: Ethnographic knowledge and the making of the Soviet Union. Ithaca: Cornell University Press. 
Jaworski, Adam \& Crispin Thurlow. 2010. Introducing semiotic landscapes. In Adam Jaworski \& Crispin Thurlow (eds.), Semiotic landscapes: Language, image, space, 1-37. London \& New York: Continuum.

Kallen, Jeffrey L. 2010. Changing landscapes: Language, space and policy in the Dublin linguistic landscape. In Adam Jaworski \& Crispin Thurlow (eds.), Semiotic landscapes: Language, image, space, 41-58. London \& New York: Continuum.

King, Charles. 2000. The Romanians: Romania, Russia, and the politics of culture. Stanford: Stanford University Press.

Landry, Rodrigue \& Richard Y. Bourhis. 1997. Linguistic landscape and ethnolinguistic vitality: an empirical study. Journal of Language and Social Psychology 16(1). 23-49.

Muth, Sebastian. 2012. The linguistic landscapes of Chisinau and Vilnius - LL and the representation of minority languages in two post-Soviet capitals. In Durk Gorter, Heiko F. Marten \& Luk van Mensel (eds.), Minority languages in the linguistic landscape, 204-224. Basingstoke: Palgrave Macmillan.

Nygren, Bertil. 2008. The rebuilding of Greater Russia. Putin's foreign policy towards the CIS countries. London \& New York: Routledge.

Pavlenko, Aneta. 2008. Multilingualism in post-Soviet countries: Language revival, language removal, and sociolinguistic theory. International Journal of Bilingual Education and Bilingualism 11(3/4). 275-314.

Pavlenko, Aneta. 2009. Language conflict in post-Soviet linguistic landscapes. Journal of Slavic Linguistics 17(1/2). 247-274.

Pavlenko, Aneta. 2010. Linguistic landscape of Kyiv, Ukraine: A diachronic study. In Elana Shohamy, Eliezer Ben-Rafael \& Monica Barni (eds.), Linguistic landscape in the city, 133-154. Clevedon: Multilingual Matters.

Pavlenko, Aneta. 2011. Language rights versus speakers' rights: On the applicability of Western language rights approaches in Eastern European contexts. Language Policy 10(1). 37-58.

Pennycook, Alastair. 2009. Linguistic landscapes and the transgressive semiotics of graffiti. In: Elana Shohamy \& Durk Gorter (eds.), Linguistic landscapes: Expanding the scenery, 302-312. London \& New York: Routledge.

Pietikäinen Sari, Pia Lane, Hanni Salo \& Sirkka Laihiala-Kankainen. 2011. Frozen actions in the Arctic linguistic landscape: A nexus analysis of language processes in visual space. International Journal of Multilingualism 8(4). 277-298.

Rannut, Mart. 2008. Estonization efforts post-independence. In Aneta Pavlenko (ed.), Multilingualism in post-Soviet countries, 149-165. Clevedon: Multilingual Matters.

Reh, Mechthild. 2004. Multilingual writing: a reader-oriented typology - with examples from Lira Municipality (Uganda). International Journal of the Sociology of Language 170. 1-41.

Scollon, Ron \& Suzie Wong Scollon. 2003. Discourses in place. London \& New York: Routledge.

Sloboda, Marián, Eszter Szabó-Gilinger, Dick Vigers \& Lucija Šimičić. 2010. Carrying out a language policy change: Advocacy coalitions and the management of linguistic landscape. Current Issues in Language Planning 11(2). 95-113.

Smagulova, Juldyz. 2008. Language policies of Kazakhization and their influence on language attitudes and use. In Aneta Pavlenko (ed.), Multilingualism in post-Soviet countries, 166-201. Clevedon: Multilingual Matters.

Trumper-Hecht, Nira. 2009. Constructing national identity in mixed cities in Israel: Arabic on signs in the public space of Upper Nazareth. In Elana Shohamy \& Durk Gorter (eds.), Linguistic landscapes: Expanding the scenery, 238-252. London \& New York: Routledge. 